\title{
The Islamist Maktab-Quran in Iran and Its Challenges for Kurdish Nationalism
}

\author{
Jamal Khosravi, \\ Lecturer at the Department of Social Sciences, Paym-e-Noor University, Iran \\ Hossein Aghapouri ${ }^{1}$ \\ School of Social Sciences, The University of Auckland, New Zealand \\ Loghman Hamehmorad \\ Instructor at the Department of Social Sciences, Payam-e-Noor University, Iran
}

\begin{abstract}
The MaktabQuran (MQ), or School of Quran, is the oldest Sunni Islamic political ideology in Iranian Kurdistan. Throughout the forty years of its existence it has gone through many semantic changes. This paper analyzes the discourse formation of the MQ under development within the broader domain of the Kurdish nationalist movement. Moreover, these discursive changes were mostly in response to certain developments in regard to mainstream Iranian Islamist ideology, and also the Iranian central government's changing approach to Kurdistan. The paper provides a conceptual explanation of the MQ's discourse. It discusses the way the discourse has changed over the years, and relates the changes to various external factors, specifically, the social and political macro-changes in Kurdistan and in Iran. Studying the social acts of the MQ's discourse from the perspective of the dominant discourse of Kurdish nationalism reveals the dialectic relationship between these two phenomena. In fact, as a result of the presence and expansion of Kurdish nationalism, which diverged from the approach of the central government, a broader social action emerged which has provided a ground for the discourse analysis of the MQ's practices.
\end{abstract}

Key Words: Islamism, Iranian Kurdistan, Ahmad Moftizadeh, Maktab Quran, Kurdish Nationalism, Discourse Analysis

\section{Introduction}

Many social thinkers in the 19th century predicted a decrease in the importance of religion in industrial and modern society (Haynes, 2009; Norris \&Ingelhart, 2011; Riesebrodt\&Konieczny, 2010; Steve, 2009). Nevertheless, "three pivotal events including the Iranian revolution in 1979, the fall of Berlin wall in 1989 and the attack on the Twin Towers in 2001." The striking thing about all of these episodes is Western social science failed completely to see what was coming (Davie, 2010, p. 160-1). For example, Berger announced the "death of secularization theory" and to him "a secular modernity never really happened (cited in: Martin 2010, p. 132). Thus, "religion has returned, famously and controversially, to human thought and culture, and this return is a political return" (Crockett, 2011, p.2), and as Toft et al. argued convincingly, religion's international influence has been increasing since the 1960s (cited in: Sandal and Fox 2011, p.1).

The processes of modernization and secularization in Iran dates to the mid nineteenth century at which time society underwent transformations in religious institutions, political structures, and so forth (Mirsepassi, 2000). Later, by his westernization and secularization programs Reza Shah put a tightening control over religious schools. This even included that the wearing of clerical garb and turban was forbidden and many other rigid restrictions were imposed on the clergymen's lives. Mohammad Reza Shah also pursued this method in a chain of structural changes that in 1963 he himself called the "White Revolution" (Abrahamian, 2008; Ghobadzadeh, 2015; Karimi, 2013). Even though traditional Islamic groups did not tolerate this process that included the western modernization of Iran they were not that powerful enough theoretically and logistically to challenge such government sponsored programs (Karimi, 2013). Yet, in the 1960s Islam was 'reinterpreted' and revitalized by Ali Shariati, a revolutionary Shiite religious thinker who tried to transform traditional/conventional Islam into a social, economic and political ideology (Abrahamian, 2008).

Islamism (political Islam), in Iranian Kurdistan, was formed by Ahmad Moftizadeh in the 1960s along with the emergence of the political Shiite discourse in Iran. Prior to that time Islam had existed in a conservative or traditional form and it was integrated with Kurdish nationalism (Mofidi, 2006). In the 1960s around the time of the emergence of Iranian political Islam, many Kurds who were practicing Islam stopped leaning on their ethno-national identity and opted for the political Islam of the

\footnotetext{
${ }^{1}$ Correspondence author's email: hagh577@aucklanduni.ac.nz
} 
MaktabQuran (MQ). This was actually an opposing or alternative project to both Kurdish nationalism and certain conservative/traditional Islamic sects in Kurdistan. In 1979, the Islamic Revolution of Iran deepened the gaps between Kurdish Islamism and Kurdish nationalism. Thus, the MQ gained more importance within an Islamic revolutionary era while Kurdish nationalism was marginalized. Nonetheless, the hegemonic influence of Kurdish nationalism and the later tensions between Ahmad Moftizadeh and the Iranian government prevented the MQ from playing an effective role in the realization of its political Islamic agenda.

The ebb and flow of Kurdish nationalism and its divergence from the Iranian center-oriented discourses have also influenced the MQ's discourse. Therefore, the conceptual explanation of this discourse and its changes are to be investigated and understood within the broader domain of the sociocultural and political developments both in Iran and in Kurdistan. Thus, in addition to an examination of the discourse of the MQ and the charismatic role of its leader(s), the external and structural factors surrounding its formation are to be considered. Although the aim of this study is to present and explain the discursive changes that have occurred in the MQ, it evaluates the evolution of this school of political Islam in the broader context of various macro-social changes in Kurdistan. This is due to the fact that the formation of the MQ's discourse at the beginning was not only related to Islamism in Iran and Kurdish nationalism. It is also related to the emergence of the Islamic Republic in 1979 and its expansion in Kurdistan which helped the advancement of this religious discourse (Mofidi 2015). The MQ influenced its members and their practices inversely in different historical periods due to the different socio-cultural dynamics present in Kurdistan. Narrating the realities of the society according to their Islamist interpretation of the world resulted in certain social and political consequences in Iranian Kurdistan, most importantly, the way they clashed with Kurdish nationalism. Thus, in regard to the discourse of the MQs, the way the concepts and the realities were being formulated had many short term and long-term effects on Kurdish nationalism as well as on the Sunni community in Iranian Kurdistan.

\section{Methodology: Islamist discourse within a discourse analysis framework}

Discourse analysis is to understand and evaluate social phenomena and their relationships together, as well as the ways in which they transform society. According to Laclau and Mouffe (1985) almost all socio-political phenomena are discursive. In fact, the arena of discourse is not only limited to the social usage of language, rather it is a space in which individuals obtain a specific understanding and interpret their surrounding world. From this approach, the act of prohibiting an election or celebrating a special day other than the day officially announced in the country, namely, Eid-al-Fitr has the same verbal message as a broadcasting media or online website may convey. In other words, although discourse is a semiotic system with a structure similar to the sign system of language, it extends to a far more vast space than that occupied by language, and even determines how language is to be used in this space (Jorgensen \& Phillips 2002; Laclau, 1990). In this space, not only is language formed in a particular way, it also includes all the acts, behaviors, and beliefs of social actors and objects that are demarcated and given meanings.

Within the domain of discourse studies, Critical Discourse Analysis (CDA) presents a better understanding of groups and societies by focusing on the dialectic relationships between the practices of the discourse and other social practices to find out the causes and effects of the discursive changes (Van Dijk, 1993; Fairclough, 1995a). As a result, it will be more likely that researchers will be able to evolve, garner, and trace authentic conclusions. In fact, discourse is a kind of social practice that forms the social world around it and is established or shaped by other social practices (Fairclough, 1992). Therefore, the discursive aspects alongside other aspects of social practices construct the outlook to interpret the world.

However, the aim of this theoretical framework is to introduce an integrated approach that allows the study of discursive changes in the ideology of the MQ in conjunction with a consideration of other social changes that are related and relevant to the context of Iranian Kurdistan in which the group is placed. However, analyzing the discursive transformation and the evolution of the MQ requires a historical method, which can clearly explain the relationship between the discursive domain and the non-discursive domain. Therefore, the case study of the MQ's religious discourse is best accomplished via an ethnographic method that requires the researcher to dive more deeply into the social life of the group that is the subject of the study.

Spending about 12 months (September 2009- September 2010) in the heart of this religious discourse has given the researchers a live reflection in relation to the MQ's point of view of the surrounding world. The dominant methods of collecting the data for this research include: participation observation, and participating in discussions, debating with renowned people in this movement, recording member statements, and the analysis of many other written, oral and visual texts associated 
with this discourse ${ }^{2}$. All of the newspapers that were reviewed for this research were around the time during the Islamic revolution of 1979.

Most of the Farsi and Kurdish resources used in this research are from the daily newspapers and announcements published before, during and after the revolution of 1979 in Iran. What makes this current study very valuable is that there has not been a deep and academic study of the Maktab Quran and political Islam in Iranian Kurdistan prior to this research. Thus, this research can be regarded as a first effort to study the formation and development of the MQ or political Islam in Iranian Kurdistan by focusing on the discursive development of this school. As far as the authors are aware, this is the first and only reliable work in English on the political Islam of the MQ in Iranian Kurdistan.

\section{An outline of Kurdish Nationalism's disposition toward religions in IranianKurdistan}

The meaning of Kurdish national identity could be outlined as a common culture, language, territory, set of symbols, memory and experience and future political aspirations (Sheyholislami 2011). Accordingly, Kurdish groups would be distinct from Arab, Persian and Turkish groups, even if their religious and ideological sentiments overlapped in certain cases. As Chris Kochera (2000) indicated Kurdish movements passed three phases, including feudal, religious and political phases. While a specific social class took the lead at each phase in the movements, the most common trait at all the stages was the national question of the Kurds.

Kurdish nationalism in Kurdistan was mostly about unifying all social activities to articulate a different and distinguished national identity for the Kurds. The Kurds believe that establishing their own independent state, or access to the ethnic/national rights through various forms of selfdetermination, such as, federalism or autonomy are the basic rights which they have been deprived of during the process of formation of the modern nation-states in the Middle East (Ghassemlou 1965, Van Bruinessen 1989, Kreyenbroek 1992, Van Bruinessen 1992, Vali 2011). The political dimension of Kurdish identity derives from its relationship with, and, as a reaction to the establishment of modern nation-states in Iran (Vali, 2011). Needless to say, this discourse aims at unifying the Kurds of the four adjacent countries (Iran, Iraq, Turkey, and Syria) in a more emotional sense (Eagleton, 1963).

The crucial signifier of this discourse has been a kind of nationalism focused on embracing social unity and establishing an autonomous Kurdish government within the territories of the countries that have encompassed Kurdistan. Kurdish nationalism was not only a politically salient phenomenon pursued by activists, it is also visible and highly influential in terms of all aspects of Kurdish life, including the arts, literature and poetry (Ahmadzadeh, 2003; Pirbal, 2008). In Iranian Kurdistan, Kurdish nationalist practices aimed at debasing the elements of Iranian and Persian identity and aimed to develop a uniquely Kurdish society within Iranian sovereign territory ${ }^{3}$ (Kochera 2000). In fact, the discourse of Kurdish nationalism required the provision of a meaningful framework for separating the Kurds from the Iranian and Islamic identity, as it was perceived that it would not be possible to create an autonomous government without such a framework.

Kurdish identity has been mostly defined with respect to the Kurdish 'ethnie' (Smith 1986), by focusing on Kurdish ethnic and cultural identity. The dominance of nationalism in Kurdistan was so powerful that the prolonged presence of religious narratives did not pose serious threats to the national aims. For social groups and individuals in Kurdistan, 'being a Kurd' and being identified as Kurdish were prioritized over other identity elements. In other words, belonging to the Kurdish nation defined and determined the Kurdish life style, identity, and existence (Mustafa Amin, 2005; O'balance, 1995; Vali, 2003). For example, during the Republic of Kurdistan in Mahabad (1945-46), and almost throughout all of the Kurdish uprisings religious figures have played a significant role in stimulating an ethno-nationalist awareness among the masses (Mofidi, 2015).

Kurdish nationalist discourse did not explicitly act against Islam in Kurdistan and tried to internalize, integrate, and localize Islamic ideals to serve its own agenda (Hemn, 1979; Mofidi, 2015; Sabir, 2006). At the heart of such an approach, the insight existed that Islam was a dynamic power and tradition that could be used in service of Kurdish nationalism. Even so, the importance or priority of 'being Kurd' over 'being Muslim' reveals that religion was imagined ultimately to be subordinate to Kurdish nationalism.

\footnotetext{
${ }^{2}$ Other materials analyzed included statements, reports, speeches, CDs, books, booklets, educational classes, and every form of dialogue made and letters given to others by the members of this group. Members' life style (clothing, type of cars, and unwillingness to participate in governmental ceremonies) was also believed to be part of MQ's discourse.

${ }^{3}$ For example, New Year (Newroz), on 21 March, is celebrated by both Kurds and Persians in Iran and the Kurds refer to the celebration as New Year 's Day. In Kurdish legend, Newroz signifies the release of the Kurds from a tyrant, and it is seen as another way of indicating support for the Kurdish cause (for more information on the culture and society of Kurdistan).
} 
Although Kurdish society is constituted of people with various religious and social backgrounds, Kurdish nationalism still considers it as one ethnicity which is the determining factor of a person's social identity and ignores the religious differences in Kurdistan. For instance, the inclusion of the provinces of Kirmashan [Kermanshah] and Ilam (whose people are predominantly Shiite) into the boundaries of Great Kurdistan on the map, demonstrates the way in which Kurdish nationalism has deemphasized the religious elements in its demarcation of Kurdish identity.

The democratic party of Iranian Kurdistan (PDKI) has been the oldest organized political party seeking a nationalist demand in Iranian Kurdistan. In addition to the Kurdish nationalism represented by the PDKI, the political sphere of Iranian Kurdistan included some other groups, the most significant of which was 'Komala', a Marxist-Leninist and Maoist group. An interesting point about Komala is that a Kurdish religious-nationalist clergy, ShiekhEzzadin Husseini, was the leader of such a leftist group for many years during and following the Iranian revolution in 1979.

\section{The backgrounds and the birth of the Political Islam of MQ}

The political aspect of Islam in Iranian Kurdistan has been utilized most effectively by the founder of the Maktab Quran (MQ) Ahmad Moftizadeh. Because of his sympathy to the social background of the wide-ranging Shiite Islamic groups in Iran, Moftizadeh was one of the first persons considered to be an 'other' in relation to Kurdish nationalism and conventional/traditional religious practices in Kurdistan. The public demonstrations of 5 June 1963 in Iran $^{4}$ greatly influenced his thought (Moftizadeh, 1979). Moftizadeh's 'religious background' (Burhan, 2006) and his 'previous nationalist activities' (Mofidi, 2004, p.91; Muhtadi, 2008, p. 2) gave him an important position among the Kurdish religious and political figures of his time. He was also in close contact with Shiite leaders and groups (Moftizadeh, 1980) and interacted with the broad Islamist movement in Iran. As he had taken part in the activities of the Democratic Party of Kurdistan (PDK-Iran) in Tehran, he was also well aware of the issues and problems surrounding Kurdish nationalism. This experience helped him to open a dialogue and bring about a discourse on Islamism into Kurdistan for the first time. According to Moftizadeh (1979), his discourse both narrated the problems of the Kurds and revealed answers yet to be discovered, questions facing the Kurdish nationalist aspirations.

Based on Moftizadeh's Islamist discourse, the concept of Kurdayeti [Kurdishness] and all of the associated social activities were to be redefined (Koohi-Kamali, 2005). With the stimulating energy of the overall Shiite Islamic movement and the salient tension between MQ and Kurdish nationalism (Ahmadi, 2008), the redefinition of these concepts was planned to be totally oriented to a religious and Islamic understanding. The gap between Kurdish nationalist groups in the 1960s was accompanied by a tense relationship between religious discourse in Kurdistan and Islamism throughout Iran. This was also a time where the salience of Kurdish nationalism had reached new lows in the new social sphere, especially in the southern parts of Iranian Kurdistan which is mostly inhabited by Shiite Kurds.

Until the 1960s, the religious intellectuals who were taking part in social activities served Kurdish nationalism and exploited Islam and subordinated it to Kurdish ethno-national identity. Yet, due to the weakening of Kurdish nationalism in the 1960s, there were greater incentives to articulate an identity that had a greater religiously orientation and a more open social vision. Thus, they started to focus on Islam and criticized and rebuked traditional Kurdish clergies and religious superstitions, especially Sufism [Mysticism] (Aliyar, 2006).

Historically, Kurdistan had been the favorable place for several mystic sects, such as, Naqshbani and Qaderi ${ }^{5}$. As these groups were self-supporting and independent from the central government, they could easily settle tribal conflicts. Whilst Sufism (Mysticism) was a stable and dignified sect in the view of people, some tribes identified themselves as mystic groups (Van Bruinessen, 1992). After World War II and the development of Kurdish nationalism, these groups were regarded as superstitious sects and were severely criticized. Certain critical discourses argued that Sufis and their practices led people to laziness, and claimed that their leaders and clergies accumulated huge wealth in the name of religion and God. These sects were mainly regarded as the reason for the social backwardness of the

\footnotetext{
${ }^{4}$ The demonstrations (also named uprising) of 5 June 1963, in Iran were a set of massive public marches against the detention of Ayatollah Khomeini following a fuming speech by him attacking the Iranian Shah, Mohammad Reza Pahlavi, United States and Israel. Although these were quenched quickly by the government, the events acknowledged the significance and power of (Shiite) religious opposition to the Shah (see, Moin, 2000, p.104).

${ }^{5}$ Naqshbandi and Qaderiare two major spiritual orders of Sufism prevailing in Kurdistan. Although there are some differences between them they mainly trace their spiritual lineage to the Islamic prophet Muhammad, through Abu Bakr, the first Caliph, or through Ali, Muhammad's cousin, son-in-law and the fourth Caliph, in keeping with most other Sufis (see, Kabbani, 2004, p.557).
} 
Kurdish society (Aliyar, 2006). The perceived cooperation between the Sufis and the Iranian governments resulted in critiques accusing them of collaborating with the government. This would mobilize the people in Kurdistan against this belief system and the tribes associated with them.

These criticisms had a considerable effect on the formation of Islamism in Kurdistan. The strong statements of Moftizadeh during the inception of the MQ and the development of its activities led Islamism to overcome previous traditional religious discourses, such as, Sufism. Hence, according to the MQ's agenda, Islam has a different meaning from that which was known before. Here, it is introduced as a political, sociological, and economical school. The discourse mainly focused on the human nature of Muslims, especially while Islam speaks about the development of human beings and societies. Concepts like ethnicity and autonomy were mostly marginalized and excluded. In Moftizadeh's discourse, the Kurds' problems essentially became those of the whole Islamic world. He placed the Kurdish issue under the broader aegis of Islam, and asserted that such problems could be solved through a universal (instead of a local) schema.

In contrast to the Kurdish nationalist discourse that was seriously focused on the right to selfdetermination and diverged from the central government of Pahlavi, the MQ mostly focused on convergence to the center and compromised with the government. As such, the MQ discourse did not define Kurds as inherently 'other' to Pahlavi and the Iranian central government. Such a departure from 'Kurds as self' against 'non-Kurds as others' was an implicit rejection of Kurdish nationalism, and a rather systematic acceptance of political Islam (Mofidi, 2015).

Moftizadeh's criticism of conservative and traditional Islam was influenced by Ali Shariati's concerns in relation to the transforming of Islam into a social and political ideology and from a set of sporadic knowledge to a systematic organization. Shariati criticized the secular sovereignty in a religious context and he preferred Alavid Shiite and Nabavids Sunni over the Safavids Shiite and the Umavids Sunni (cited in Gheissari, 1998). Similar to Shariati, Moftizadeh introduced Islam as a fundamental ideology that seeks the unification and the transformation of the world. Based on such religious logic, the question of the Kurds should be answered by referring to other general questions of humanity during a time of change (Amini, 2005). By focusing on the concept of humanity, the MQ developed the raison d'être of the Maktab Quran [School of Quran] that pointed to a universal state in the world of Islam. So, the aim of the foundation of several MQ seminaries in Kurdish cities represented a new focus on the general Quranic law and avowedly devaluated Kurdish nationalist projects.

\section{The Maktab Quran in the early days of the Islamic revolution of Iran in 1979}

The Pahlavism ideology and the regime of Mohammad Reza Shah encountered the crisis of legitimacy in the 1970s and finally collapsed in 1979. The new circumstances subsequent to the 1979 revolution brought about an opportunity for micro-discourses previously suppressed by Pahlavism to re-emerge in the form of political parties and organizations in Iranian Kurdistan. The main discourses competing for influence in Kurdistan were Kurdish nationalism, Marxism and Islamism. The discourse of the Islamic Revolution provided an ideal context for all of the representatives of these discourses, including MQ (Islamist), Democratic Party of Iranian Kurdistan (nationalist), and Komala and Cherike-Fadayi (Marxist-Leninist), to stipulate their ideological blueprints in Kurdistan's political discourse (Kochera, 2000). Owing to the domination of a broad and generalized utopian revolutionary discourse, the signifier of the elimination of oppression regarding the Kurds became the rallying cry of Kurdish nationalism, Marxism, and Islamism alike, despite their fundamental differences (see Figure 1). In other words, the cohabitating moments of the three discourses in the Kurdish political landscape were temporal and were affected by the condition provided by the revolution and the key signifier of the elimination of oppression regarding the Kurds. 
Figure 1: Islamist, Marxist, and Kurdish nationalist discourses and their framing by reference to the utopian atmosphere of the revolution's discourse.

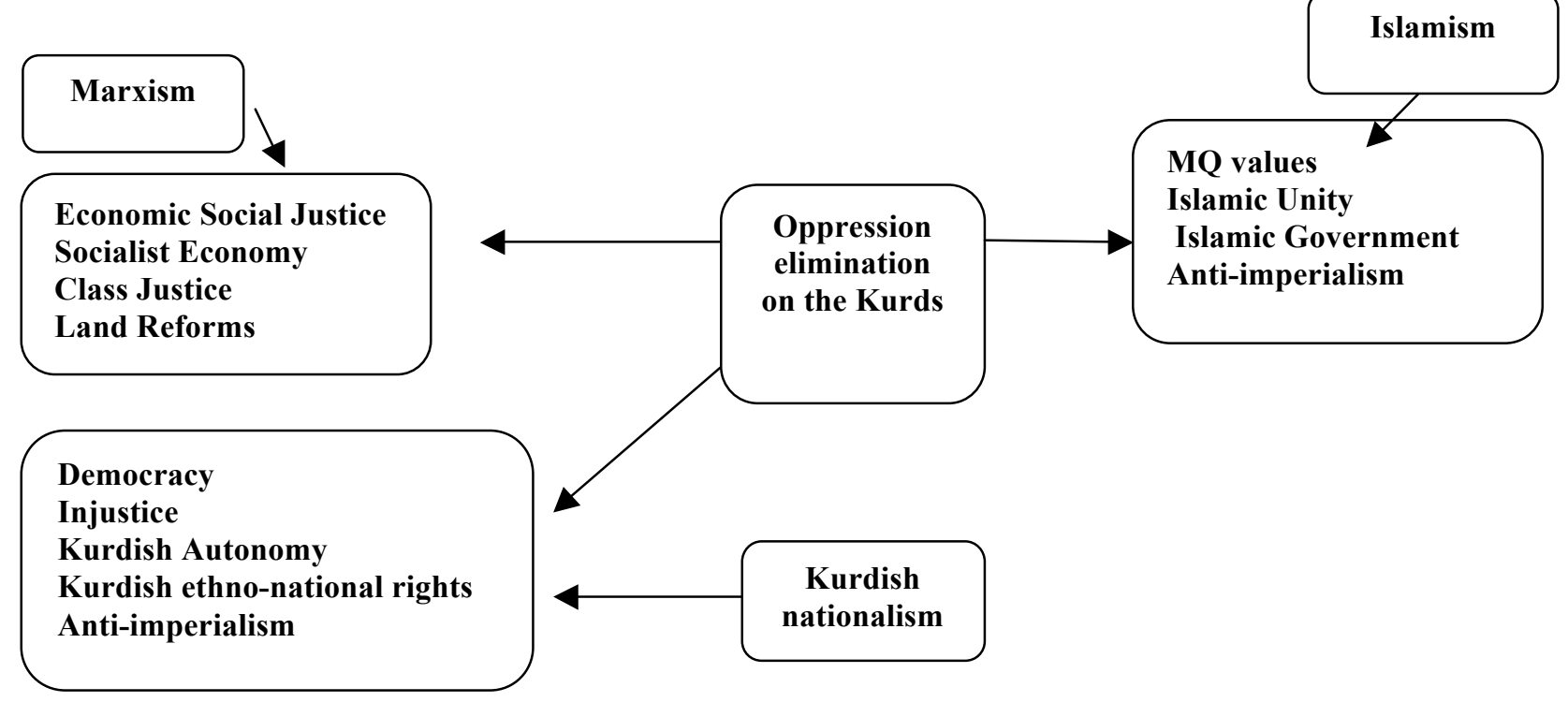

\section{The MQ's discourse articulation during the early clashes of the Kurds with the Iranian government}

While a new political system was being established in the aftermath of the Islamic Revolution and a new constitution was written, the opposing tendencies of the three discourses and their ideological tensions became clearer than during the revolution. The fact was that it was not possible for all discourses to realize their ideals within the new political system and its constitution.

After the revolution took place, the government's garrisons were disarmed by the Kurds in some Kurdish cities (Ettelaeat, 31 January 1979). For example, in Mahabad and Sanandaj, Kurdish political parties were taking over the governmental buildings. This gave a new life to the existence of the Kurdish ethno-national identity. In other words, "Kurdistan, actually, became a free and semiautonomous region in Iran" (Keykhosravi, 2003, p.88). Consequently, the Kurdish 'revolts' and events became the most important concern of the transient government of Mehdi Bazargan (P. 89). On 17 February 1979 the Bazargan government delegated a group led by DariushForuhar to negotiate with the Kurdish parties in Mahabad. The Kurdish representatives proposed an eight-article autonomy-based request to the government. In fact, autonomy was the bottom line of all non-Islamic parties in Kurdistan (Koohi-Kamali, 2005).

The MQ complained that the eight-article proposal did not include any reference to Islam (Ettelaeat, 28 February 1979). Moftizadeh himself noted that there was not any Islamic trace within the request (Moftizadeh, 1979, cited in Keyhan Newspaper, 26 \& 27 March 1979; Ettelaeat, 19 June 1979). This represented the first ideological tension between Islamism, on the one hand, and Kurdish nationalism and Marxism on the other hand, in Iranian Kurdistan. The Moftizadeh's speech that followed Ayatollah Khomeini's speech in the clerical city of Qom (Ettelaeat, 29 March 1979) demonstrated the bond between the MQ and the Islamic Revolution, and also led to more serious tensions with the nationalists and Marxists groups in Kurdistan.

Figure 2 shows that the MQ attempted to include all the minor narratives that became salient during the revolution, such as, 'national injustice elimination,' 'class injustice elimination,' 'religious injustice elimination,' and 'Anti-Imperialism.' These were connected to the central signifier of the 'Islamic Revolution' in order to show the capacity of Islam to address all social, moral and cultural human-related issues. This was obviously to marginalize the power of non-Islamic discourses. Moftizadeh deeply believed in the Revolution and its 'problem-solving capacity' and argued that from the bottom of his heart he will protect the revolution from the dangers threatening its existence and continuity (Moftizadeh, 1980). The concept of the revolution in his discourse meant that he supported the determination and swiftness of the post-revolutionary government in establishing an Islamic sovereignty in Iran (Moftizadeh, 1980). 


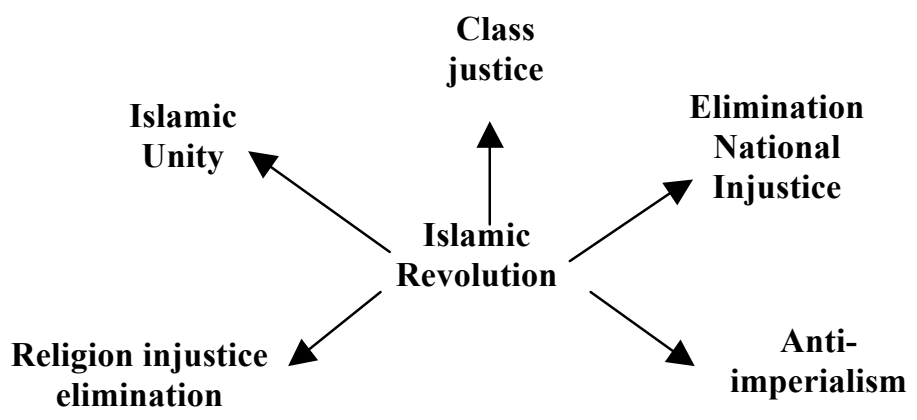

Figure 2: Biarpayin The MQ's discourse following the early clashes of the Kurds with the Iranian central government.

\section{The MQ's discourse became more opposing to the Kurdish nationalists and Marxists}

By issuing a three-article-declaration during the Kurdish uprisings following the revolution, the MQ introduced its political raison d'être based on the removal of religious, class and national oppression. It also articulated its position on issues, such as, Sunni and Shiite unity, Imperialism, Islamic economy, Islamic autonomy, and constitutional Law, among others (Keyhan Newspaper, 26 March 1979). The boycott of the referendum on the Islamic Republic government in Iran by all Kurdish nationalists and marxist parties, and the announcement of a wide-range war against the Kurds by Ayatollah Khomeini on 21 May 1980 hindered the negotiations ${ }^{6}$. Hence, this resulted in more divergence between the Kurds and the central government.

While Kurdish parties boycotted the referendum, "because of the vagueness of the new Islamic republic in Iran, and its hesitation regarding the autonomy in Kurdistan (Ghasemlou 1979), Moftizadeh in Tehran (through a radio message) encouraged the Kurds to take part in the referendum on 1 April 1979 (Mofidi, 2006). This controversy intensified the tension between the MQ and Kurdish nationalists and the Marxist parties. Thus, in the process of 'other making', the Kurdish nationalist and Marxist discourses defined the MQ members as JASH [traitor, or mercenary] (Sahabi, 2003). Meanwhile, the MQ's discourse gradually redefined its 'others' in a way to give less importance to domestic others (Kurdish nationalists and Marxists) by highlighting the external others (including imperialism). In this discursive conflict, the association of its internal others with external others was a helpful strategy for the MQ to marginalize its rival discourses. During this period of time, the MQ placed its definition of otherness as the central signifier of anti-imperialism (see Figure 3)

\section{Islamic autonomy}

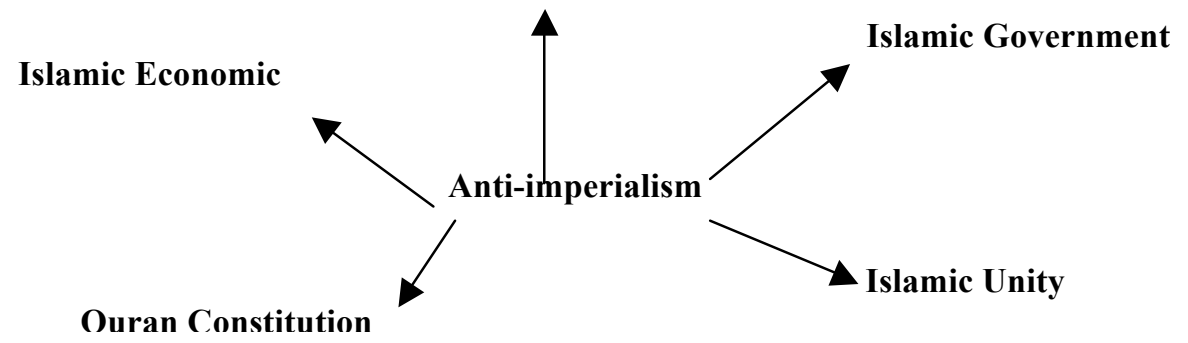

Figure 3: The MQ's discourse became more opposed to the Kurdish nationalists and Marxists

Anti-Imperialism in this period was emphasized so much that it became the benchmark of all the MQ's tendencies. Further, Moftizadeh became concerned about the "revolution's failure to meet the Kurds' political wishes, which eventually resulted in people becoming more inclined towards the nonIslamic parties" (Moftizadeh, 1980, p.91). Thus, at this time, the emergence of such signs as Islamic autonomy and Islamic economy entered into the discourse of the MQ that demonstrated its contrast to Kurdish nationalism and Marxist discourses. Moftizadeh, by proposing the concept of Islamic equality and Islamic autonomy, attempted to articulate a different sort of autonomy in Kurdistan that prioritizes

\footnotetext{
${ }^{6}$ This attack is also referred to as the 'bloody spring of Sanandaj' by the Kurds.
} 
the Islamic principles over Kurdish ethno-nationalism (Moftizadeh, 1980). Moftizadeh invited all parties to take part in a conference focused on discussing autonomy in Iranian Kurdistan to take place in Sanandaj. Yet the conference was boycotted by the Kurdish secular parties, and could not reach its missions (Ayandegan, 11 June 1979). The discursive conflicts between Islamism and secularism (Kurdish nationalists and Marxists) grew stronger during the time the MQ announced a 'fifteen-article declaration of autonomy' as a result of the Sanandaj conference (Moftizadeh, 1979). However, the removal of religious oppression in this declaration was noticeably accompanied by the removal of national and social oppression, while in the eight-article declaration of secular parties, there was no such mention of religion. In the framework of Kurdish nationalism and Marxist discourses, the signifier of Kurdish autonomy was conceptualized in relation to the phenomenon of democracy for Iran (Ghasemlou, 1979). It thus differed greatly from that of the MQ, which conceptualized Islamic autonomy as only being meaningful in the context of Islam and the Islamic government, and thus did not place as high a priority on the goals relating to the set-up of a legitimate democracy.

Alongside tensions occurring between the MQ and Kurdish nationalism from the first quarter of 1978, Moftizadeh held successive negotiations with the leaders of the revolution. However Moftizadeh stated that "due to the fear which I had of the weakening of the revolutionary government, and allowing the return of imperialism, I did not criticize the revolution"(Moftizadeh, 1980, p.63). After proposing the constitutional draft by the Iranian government, where in the thirteenth article in which the issue of officialization of Shiite Ja fari ${ }^{7}$ jurisprudence was mentioned, Moftizadeh's criticism against the revolution's leaders commenced (Etelaat, 19 June 1979).

\section{The MQ becomes more divergent from the center}

The failure of the Islamic government to address and recognize Kurdish claims led to the growth of more secular groups and the waning of the MQ in Kurdistan. The turmoil of the three-month war between the Kurds and the new Islamic government of Iran in Kurdistan instigated a certain prevailing pessimism and mistrust regarding the Shiite religion and the Iranian government in the Kurdish regions (especially in the Sunni areas) of Iranian Kurdistan (Sabaghian, 2003; Sahabee, 2003; Shahveisy, 2005). In this situation, Moftizadeh, in his speech , 'the last meeting, the last word', made his criticism open and finally, following the increasing tensions between the MQ and Kurdish political groups, Moftizadeh left Sanandaj, even though, Kurdistan was still in a chaotic situation and experiencing the turmoil of war.

The war in Kurdistan was ever growing. Thus, a few months after the Iranian revolution and the start of the discussions regarding the new constitution, a gradual evanescence of the revolution discourse occurred in Kurdistan. The result was a certain strengthening of the divergence-from-thecenter orientation and even more distancing of the Kurds from the central governing body. Moreover, chaos in Kurdistan during the six months after the Revolution paved the way for greater gaps between the Islamism and nationalist-Marxist discourses in Kurdistan.

Around this time, the MQ selected to disconnect from the government due to the powerful domination of a divergence-from-the-central trend in Kurdistan. Through its sharp criticism of the government and its leaders, the MQ acted to make the tendency for divergence stronger. Indeed, in those days, under the influence of the divergence discourses in Kurdistan, Kurdayeti[Kurdishness] was primarily interpreted as an anti-government narrative and act. "Although the MQ ended its coordination with the government, people still considered its members to be Jash or traitors to the Kurds and the Kurdish national movement" (Mofidi, 2007, p.101).

In this period (Figure 4), the MQ's discourse was articulated on the basis of the elimination of injustice in regard to the Sunni religion. Indeed, implicit divergence and government hatred in the social atmosphere of Kurdistan bloomed in this period by the MQ's discourse evolution in the form of a special Sunni orientation and a divergence from the Shiite government. Thus, the MQ, unlike in the early months of post-revolutionary period, amplified the divergence discourse formation.

\footnotetext{
${ }^{7}$ Counsel of Muslim World: "Ja farīschool of thought, Ja farī jurisprudence or Ja farīFiqh is the school of jurisprudence of most Shi'a Muslims, derived from the name of Ja 'far as-Sādiq, the 6th Shi'a Imam. It differs from Sunni jurisprudence in its reliance on ijtihad, as well as on matters of inheritance, religious taxes, commerce, personal status and the allowing of temporary marriage" (cited from Wikipedia, retrieved on 25 February 2015).

${ }^{8}$ This speech took place at HosainiehErshad in Tehran in October 1979.
} 


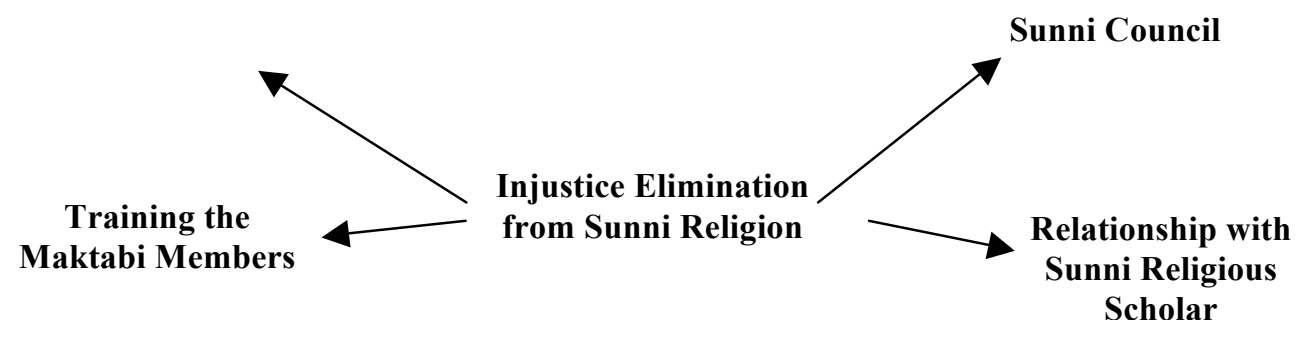

Figure 4: The MQ's discourse of divergence from the central government

Formation of contradictory convergence and divergence orientation to the central government within the MQ after the release of Moftizadeh from the Iranian prison

After the comprehensive exclusion of secularists, liberals, Marxists and other opposing groups throughout Iran by the new Islamic government during the 1980s, the Kurdish nationalist and Marxist groups were also side-lined, murdered and imprisoned. In August 1984, Moftizadeh was imprisoned by the Islamic Republic and underwent much torture. According to his followers, the tall and energetic body of Moftizadeh was pushed through a doorway while blindfolded, breaking his neck. Due to the torture he suffered, he did not live long and died on 8 February 1993, six months after his release from the prison.

The start of public visits with Moftizadeh in prison, and eventually his release from prison in the late 1980s, transformed him to a charismatic leader and made him the MQ's core signifier. The return of the charismatic leader after ten years aroused feelings in the members of the MQ in a way that led Moftizadeh to be a loving disrupter and violator of the existing models of the MQ at the time. Hence, his effect on the genesis of new concepts and experiences and its conveyance to the acts and thoughts and the language of the followers had significant sociological effects on the structure and organization of the group and won the admiration of the members who felt similar.

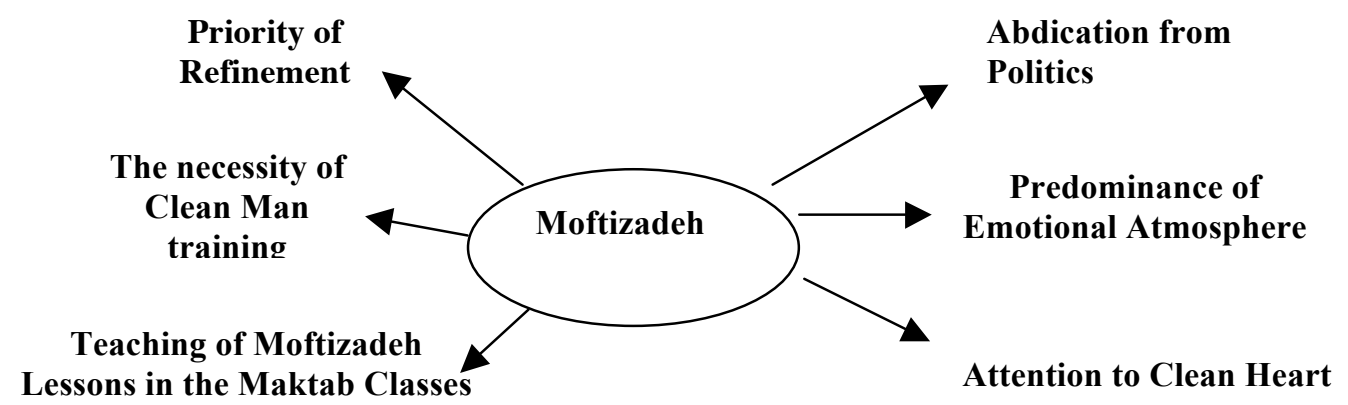

Figure 5: The MQ's Discourse since Moftizadeh's release from prison until his death in 1992.

Even so, the presence of the charisma did not last long. Upon his death in 1992, the foundation of another discourse of the MQ formed around symbols such as 'divergence from the center,' 'Moftizadeh's insight,' 'refinement,' and the 'government conspiracy towards the MQ'. Moftizadeh's belief in his consistent presence in the dream and his connection with some members, revealed that the leader's charismatic role was not bound to just his mortal body, rather it extended his presence in a new life form. In such conditions, his successor who believed himself to be Moftizadeh's 'secret keeper' strengthened the tendency of the MQ's members towards the charismatic role of the leader that was once represented by Moftizadeh himself. Concepts such as 'secrecy' and 'supervisor of the MQ's council' were all used as signifiers which influenced the articulation of MQ's discourse in the 1990s in order to give a charismatic importance to the role of Moftizadeh's successor.

The presence of these elements and signifiers indicates that, in the absence of Kurdish nationalism in Kurdistan, the MQ's discourse is being shaped and contradicted around interactions with the central government as well as a divergence from it. In other words, the MQ's divergence orientation grew in the absence of Kurdish nationalism. An emphasis on the concepts such as 'political inaction,' 
criticizing 'political freedom,' and 'asserting the vanity of intellectual and social activity' (the MQ's council of management, 2000) on the one hand, and an expansion of discussions such as the 'Path to salvation,' 'the role of guide,' 'true dreams' and "Moftizadeh's torture in the prison" on the other, occurred in order to devalue the interactionist approach, and present a divergent orientation from that of the Iranian central government.

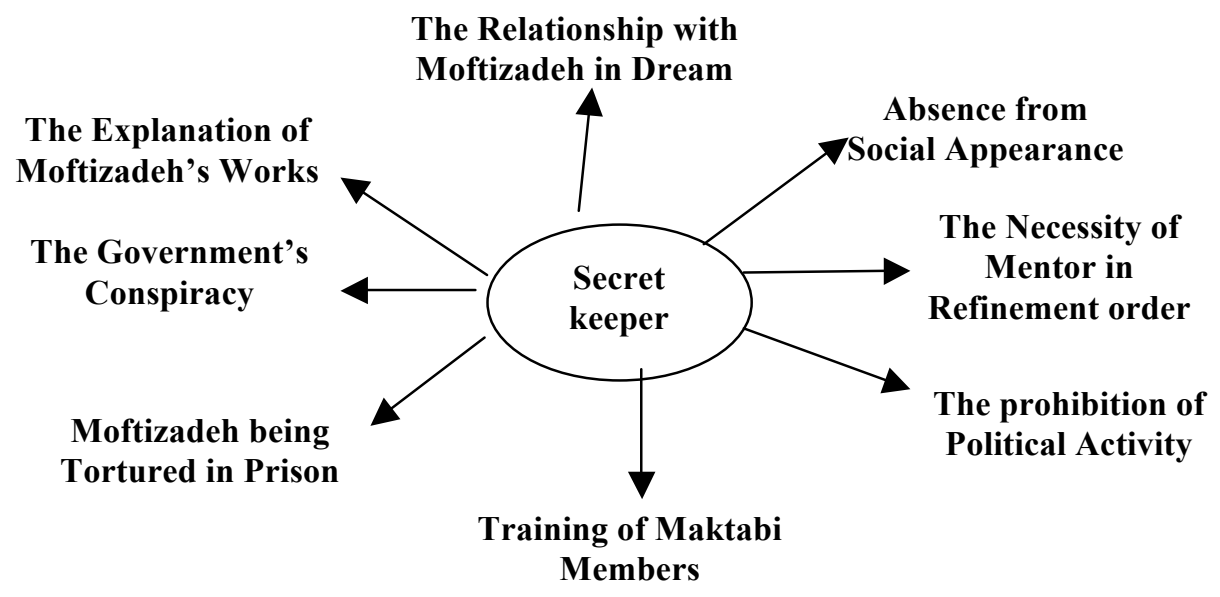

Figure 6: The MQ's discourse from 1995 onward.

With the presence of the Sunni core signifier in the 1980s, the MQ positioned its identity to contrast with the Iranian central government's Shiite's identity. Therefore, after the death of the charismatic leader and the domination of the divergent discourse within the MQ, it opposed interactionism or cooperation with the central government. This time, the identity of its members not only opposed Kurdish nationalism and Marxists, they also stood against every person and group that articulated cooperation with the central government. This recent discourse, by adding the signifier of 'government's conspiracy against the MQ', created a semantic system articulated on the basis of the assumption that all other Islamic groups are the government's agent in so far as that they were trying to provoke the MQ into cooperation with the government (The MQ's council of management 2005).

\section{Wax and wane of interactionism in the MQ}

In the late 1999s, the presidency of Muhammad Khatami and a period of reformation, provided grounds for a decrease of the MQ's divergence discourse. These years witnessed a higher participation of Kurds in the socio-political affairs of Iranian Kurdistan compared to prior times since the revolution of 1979 (Esmailzadeh, 2009). The Kurdish participation in the political, social, cultural and economic structure of the country not only diffused the untrusting atmosphere towards the government, it also reinforced the public sphere in support of a cooperating approach with the central government. Hence, it was under these conditions that the interactionist discourse made a comeback in terms of the MQ's goals. The set of signs in this interactionist discourse showed the revival of the concept of sociopolitical activities in the public ground of Iran and Kurdistan that had been latent in the MQ's discourse from its outset.

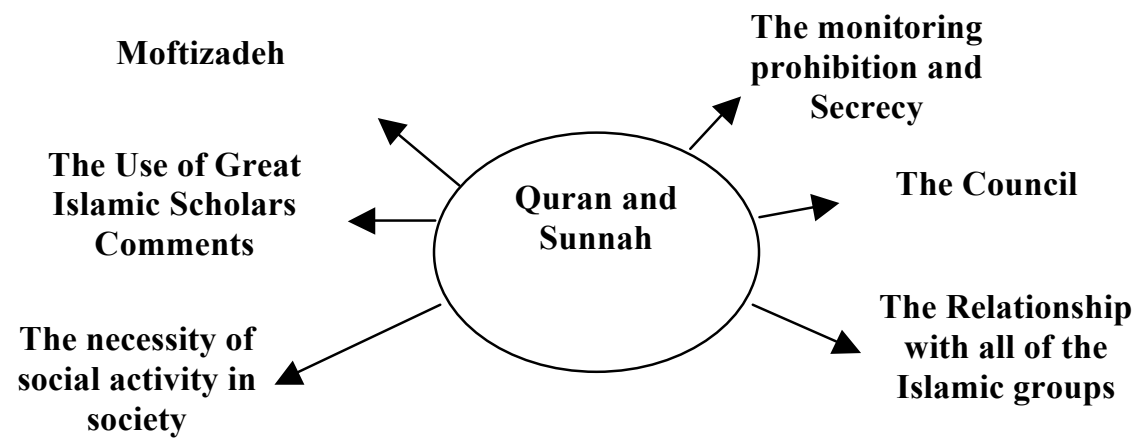

Figure 7: The Interactionist micro-discourse (Kurdistan Council of MQ) defected from MQ's dominant divergence discourse in 1997. 
The core signifier of the interactionist micro-discourse was the 'Quran and Sunnah.' It gave meaning to other signifiers, such as, the personality of 'Moftizadeh,' 'Sunni theologians' and 'sociopolitical acts.' Although the members of the interactionist group represented a minority, they tried to redefine the central concept of 'secret keeper and supervisor of the council' by introducing and giving higher importance to the 'Quran and Sunnah' signifiers (The MQ's council of management, 2000). On the contrary, the majority discourse, by introducing a different conception of 'Moftizadeh' as a signifier, related the signifiers, such as, 'secrecy' and refinement to the government's conspiracy against the MQ. They believed in the charismatic role of the secret keeper or supervisor of the MQ's council as a factor for 'nurturing people' against the corruption in the MQ aroused by the 'government's conspiracy' (The MQ's council of management 2005).

The non-realization of the plan of the Iranian reformists and the broken promises to Kurdistan caused additional mistrust between the Kurds and the central government. This resulted in a 59 per cent reduction in Kurdish participation in the 8th presidential election in Iran (Moloudi, 2009, p.208). Therefore, in the mid-2000s, the process of the gradual elimination and exclusion of interactionists took place in the MQ using different methods, such as, omitting them from council elections and labelling them as Jash. To justify this elimination, the majority discourse used other signifiers such as the government's conspiracy and re-emphasized the old and latent divergent discourse of the MQ. The conspiracy signifier, because of its vagueness, could take up different interpretations and definitions. Therefore, any threat to the articulation of the majority discourse would be deemed to be part of a conspiracy initiated by the government. Divergence advocates, who were already dominant, used several mechanisms, such as, holding public meetings for the MQ's members in several cities, and encouraging members not to have any relations with people associated with so-called interactionist people, to restrict their activities.

\section{The social and personal behaviors of the members in a discursive context}

The existing strategies of the MQ expressed the systematic effort to reduce the normative and cognitive inconsistency. Abandoning the ideological oppositions inside the group and secluding the opposed members demonstrated the group's powerful tendency towards the assimilation of the minority, as well as the weakening of the personal independency of the members. Attracting idealistic people with little tolerance for intellectual arguments and members from rather financially deprived families have been common actions in the context of the group. In such conditions, people require the approval of existing members in order to become a formal member of the MQ. Moreover, weak reasoning is not questioned at all; vain hope is not criticized; the ethics of their own group are known to be evident and the consequences of their actions are not questioned. While any opposing person is actually seen and behaved unfavorably, little if any real dialogue takes place between the MQ and 'others'. Every person conceals their doubt and uncertainty instead of being able to freely express their thoughts and feelings. In fact, 'charisma-seeking' is still a core signifier and charisma-based social order is an authoritative model of this discourse and people seek to realise their ideals though it. It seems that the follower is more like a very young and highly impressionable person or a child who cannot act without the influence and presence of the charismatic leader.

Therefore, disregarding external factors, focusing on personal will, and the prioritization of motivation and ambition rather than outcome indicates that idealism and the ignoring of rationality are still valuable norms within the discourse. From this perspective, one bestows himself to the values that he is faithful to, and in the case of necessity to protect these values he would willingly and heroically accept death. For, death is a heroic life style which is appraisable by Islamism.

\section{Conclusion}

Based on the periodic changes in the MQ's discourse as described above, the historical evolution of this ideology can be understood and summarized in five different periods. Each era has a core and dominant discourse which governed the MQ and determined its characteristics. The first era overlapped with the start of Islamism in Iran, up until the Islamic revolution in 1979. In this era, with the emergence of the Shiite political discourse in the early 1960s, Islamism in the form of the MQ's religious discourse entered into the public sphere of Kurdistan. It became an alternative for the project of Kurdish nationalism especially in the southern parts of Iranian Kurdistan.

From the outset of the Islamic revolution of 1979, the gradual presence of the MQ's religious discourse in Iran's revolution and in Kurdistan's, the issues became more evident, and the role of Islam became more pronounced. In this period (the second era), the dominant discourses in the public sphere in Kurdistan included Islamism, Marxism and Kurdish nationalism which all sought to realize their goals by reference to utopian thinking stimulated by the idealist impact of the revolution. In such a revolutionary era, different interests and contrasting ideas were compromised for the purposes of the 
higher goal of social change and the removal of the Pahlavi regime. However, subsequent to the revolution, that unity did not last long. After the formation of the new political system and the drafting of the new Constitution of Iran, the discursive contrasts and disputes between Islamism and Marxism/Kurdish nationalism became even more pronounced. During this period the MQ's Islamism and the interactionist approaches came into conflict with Kurdish nationalism even more than it had before.

The third era started with the MQ's members leaving their bases in Kurdistan province for Kirmashan [Kermanshah] city. It continued until 1982, at which time the Iranian government arrested Moftizadeh. In fact, this era could be understood as the critical turning point where the MQ moved from an interactionist approach toward the Iranian Shiite government and adopted a divergent approach from the government by focusing on the symbols and signifiers of the Sunni religion.

The fourth era started with the release of Moftizadeh from prison. Following that, he held continuous meetings with the members of the school in which Moftizadeh's personality and writings became the transcendental signifiers for the MQ's agenda. By the death of Moftizadeh, this era even became more divergence-oriented and the MQ rejected every interactionist tendency towards the central government. It tended to emphasize a more diverging orientation to the Iranian government and its Shiite religious discourse. Although a minority group has been seeking more interaction with the government, they have been marginalized by the majority discourse or divergence from the government. This era is delineated by the features of the persistent charismatic leadership that existed in terms of his successor boards and the secret keeper.

Theanalysis of the semantic system of MQ's discourse and its changes suggested that the signs within this discourse in every era revolved around a distinctive sign (focal point), which has been at the core of the dispute with Kurdish nationalist discourse in different eras. The MQ's discourse has gone through several changes in the context of national revolts and dissatisfaction in Kurdistan with the Iranian governments and in every era it has given meaning and order to its signs. Likewise, the disputes between the MQ's religious discourse and Marxism and Kurdish nationalism discourses have brought about 'otherness' for the MQ's adherents within Kurdistan's socio-political structure.

\section{References}

Abrahamian, E. (2008).A History of Modern Iran. Cambridge, UK: Cambridge University Press. http://dx.doi.org/10.1017/CBO9780511984402

Ahmadi, D. (2010). “Jam-e Shenasi-e TarikhiHezb-e Demokret-e Kurdistan-e Iran”[historical sociology of Kurdistan Democrat Party of Iran].Rojav Journal, 8, 9, \&10, 251-268.

Ahmadi, H. (1999). GhomiatvaGhimgaraidar Iran: AfsanevaWagheiat/ethnic and ethnicity in Iran (fable and reality]. Tehran, Iran: Nashr-e Nei.

Ahmadzadeh, H. (2003). Nation and novel: a study of Persian and Kurdish narrative discourse. Sweden: Uppsala University.

Aliyar, N. (2006). Salafi-ye Dar Rozgar-e Ma [Salafid in Our Times].Boukan, N.D.

Amini, H. (2005). "Yad-e Ayam: BazkhaniTarikh-e Maktab-e Quran"[In Memory of the Previous Days: A Study on the History of Makteb-e Quran]. Rah-e Ma, 25-33.

Aronson, E., Wilson T., \&Aret, R. (2010).Social Psychology.Essex, UK: Pearson Education.

Crockett, C. (2011). Radical Political Theology. New York, NY: Columbia University Press.

Davie, G. (2010). “Resacralization”.In Turner, B (Ed).The New Blackwell Companion to the Sociology of Religion.(pp 160-177), Willey-Blackwell.http://dx.doi.org/10.1002/9781444320787.ch7

Eagleton, W. (1963).The Kurdish Republic of 1946. London, UK: Oxford University Press.

Esmaeilzadeh, KH \& Abdulla, R. (2009).“Barresi TeoriRabeteBeineSarmaieEjtemaiwa

Fairclough.N. (1992).Discourse \& social change. Cambridge, UK: Polity Press.

Fairclough, N. 1995a).Critical Discourse analysis. London, UK: Longman.

Ghasemlou, A. (1965). Kurdistan and the Kurds.Prague. Pub. House of the Czechoslovak Academy of Sciences 1965

. (1979). "Goft u go Ba Rozname-ye Iran-e Farda”[Interview With Iran-e Farda Newspaper]. 19 December.

- (2004).Tavgay Hagheghat [Waterfall of Truth], A part of Dr. Ghasemlu's works. Compiled by Kawa Bahrami. Volume I. Iraq: No city. PDKI's Publication.

Gheissari, A. (1998). Iranian Intellectuals in the Twentieth Century. Austin, TX: University of Texas Press.

Ghobadzadeh, N. (2015) Religious Security: A Theological Challenge to the Islamic State. Oxford, UK: Oxford University Press. 
Haynes, J. (ed). (2009).Routledge Handbook of Religion and Politics.New York, NY: Routledge.

Hemn.M. (1979).Tarik u Run u Golbejerek Le SherekaniHemn [Dark and Bright, Hemns' Poetry].Mahabad, Iran: Saidian.

Izdy, M. (1992).The Kurds: a concise handbook. Washington, DC: Crane Russak

Jorgensen, M. \& Phillips, L. (2002).Discourse Analysis as theory and Method. Thousand Oaks, CA: Sage Publications. http://dx.doi.org/10.4135/9781849208871

Kabbani, M. H. (2004). 'Classical Islam and Naqshbandi Sufi', Islamic Supreme Council of America.

Karimi, P. (2013) Domesticity and Consumer Culture in Iran: Interior Revolutions of The Modern Era, London, UK: Routledge.

Kochera, C. (2000). The Kurdish national movement and the Will of Independence, Translated by Aziz Mamle. No place.

Keykhosravi, F. (2005).“Goft u goieWije” [Special Interview]. Journal of Chashandaz-Kurdistan, 166178.

Koohi-kamali, F. (2005).“The Development of nationalism in Iranian Kurdistan'. In The Kurds: A Contemporary Overview: 135-151. Edited by Kreyenbroek ph. \& Stefan, S. London, UK: Taylor\&Francis.

Laclau, E., \&Mouffe C. (1985).Hegemony \& Socialist strategy: towards a Radical Democratic politics. London, UK: Verso.

Laclau, E. (1990). New Reflections on the Revolution of our times. London, UK: Verso.

Mirsepasi, A. (2000).Intellectual Discourse and the Politics of Modernization: Negotiating Modernity in Iran. New York, NY: Cambridge University Press.http://dx.doi.org/10.1017/CBO9780511489242

Mofidi, S. (2006). 'Karkard-e Siasi-ye Din[The Political Function of Religion]', Rojav Journal, 1, 75 116.

Mofidi, S. (2015).Religion and Politics in Eastern Kurdistan (With a Focus on MaktabQur'an During Iranian Revolution, 1979).Journal of Politics and law,8(3), 3650.http://dx.doi.org/10.5539/jpl.v8n3p36

Martin, R (2010) Hidden Bodies in Islam: Secular Muslim Identities in Modern (and Premodern) societies. In Marranci, G (Ed) Muslim Societies and the Challenge of Secularization (pp 131148), Springer.http://dx.doi.org/10.1007/978-90-481-3362-8_9

Moftizadeh, A. (1979). Kaset-e Goft u go Ba Emam[ Discussion with Ayatollah Khomeini]. 26 March. (1979). 'payamibarayemellate Iran [A Message for Iranian Nation]', 2 October. (1979). Amanat(Dalil-e Hedaiat)[Safekeeping; for Guidance], audio cassette.

(1979). Ghatnameykonfransekhodmokhtari [Autonomy Conference's Resolution]', 12 June.

(HosseinyehErshad Audio Cassette)

- (1979). Darbareyekordestan [A pamphlet On Kurdistan].

(1979). Telegram Be Emam [Telegraph to Ayatollah Khomeini]', 19 June.

(1980). Nameyei be mardomekordestan [A Letter to the People of Kurdistan]. 30 June. (1990). General Meeting with MQ members. Decembre 1990.

(1992). Awamele-e ShakhsiatsazwaGhodrat-e Eradeh" [The Personality-Making Reasons and The Power of Will]'. May.

(1992). Dalaiel-e Man-e Kar-e Siasi [The Reason on Political Action Resignation].Video Cassette.

. (1992). "Honar-e Jamal DostiwaTafawot-e Harf-e Zehn Ba Harf-e Ghalb" [The Art of Beauty Loving and TheDifference Between Minds' Word and Hearts]. Video Cassette, February.

Places

Mohammad, A. (2006). PeyamiRasti [The Message of Truth]. Iraqi Kurdistan: Sulaymani City.

Mohtadi, S. (2008).Interview with Govari Levin[Levin magazine in Kurdish].6, 10.

Moin, B. (2000). Khomeini, Life of an Ayatollah. New York, NY: St. Martin's Press

Moludi, A. (2009). 'Mosharekat-e Siasi-ye Kordha Dar Kurdistan" [The Political Participation of Kurds in Kurdistan].RojavJournal , 4 (11.12, \& 13):223-231.

Mustafa Amin, N. (2005). Hokomat-e Kurdistan; Kurd Dar Bazi-ye Siasi-ye Shoravi [Kurdistan Government; Kurd in Soviet's Political game].Iraqi Kurdistan, Sulaymani: Jin Publication.

Nishtiman. (1943). [Nishtiman magazine: newspaper of J.K Community].1-9. 
Norris, P \&Inglehart, R. (2011).Sacred and Secular: Religion and Politics Worldwide (2 ${ }^{\text {nd }}$ edition).

Cambridge, UK:

Cambridge University Press. http://dx.doi.org/10.1017/CBO9780511894862.

O’Ballance, E. (1995). The Kurdish Struggle 1920-94. UK: Palgrave.

Pirbal, F. (2008).Tasirat-e Motaghabel-e Nationalism waAdabiat-e Kurdi [The Reciprocal Impact of Nationalism and Kurdish Literature], Rojav Journal, 3(8.9.10):431-437.

Riesebrodt, M. \&Konieczny E. M, (2010). "Sociology of Religion”, in John R. Hinnells (ed). The Routledge Companion to Study of Religion, New York, NY: Routledge.

Sabaghian, H. (2003). 'Goft u goieWije [Special interview], Nashrie-ye Chashmandaze-Kurdistan. 1: 51-60.

Sabir,R. (2006). Kultur u Nationalism [Culture and Nationalism].Iraqi Kurdistan: Sardam.

Sahabi, E. (2003). 'Goft u goieWije [special interview].Nashrie-ye Chashmandaz-Kurdistan, 1:62-72.

Sandal, N.A and. Fox, J. (2013).Religion in International Relation Theory: Interaction and Possibilities. London, UK: Routledge.

Shahweisi, H. (2005). 'Goft u goieWije [special interview], Nashrie-ye Chashandaz-Kurdistan, 2: 1230.

Sheyholislami, J. (2011). Kurdish Indetity, Discourse and New Media. Palgrave McMillan. http://dx.doi.org/10.1057/9780230119307

Smith, A. D. (1987). The Ethnic Origins of Nations. Oxford: Basil Blackwell 1987, c1986.

Stark, W. (1972).The sociology of Religion: A study of Christendom, 5 volumes. New York, NY: Fordham University Press.

Van Dijk, T. A. (1993). 'Principals of critical discourse analysis', Discourse \& society, 4 (2): 249 283. http://dx.doi.org/10.1177/0957926593004002006

Vali, A. (2003). Essays on the Origins of Kurdish Nationalism.San Francisco, CA: Mazda Publications Inc.

Vali, A. (2011). Kurds and State in Iran: the making of Kurdish identity. New York, NY: I.B. Tauris.

Van Bruinessen, M. (1992).Agha, shaikh, and state : the social and political structures of Kurdistan. London, UK: Atlantic Highlands, N.J.

Van Dijk, T. A. (2001). 'Critical discourse analysis', in Tannen, D./Schiffrin, D. and H. Hamilton (eds), Handbook of discourse analysis. Oxford, UK: Blackwell. http://dx.doi.org/10.4135/9780857028020.n1

Wodak, R. (2001). 'What CDA is about: A summary of its history, important concepts and its development', In Methods of Critical Discourse Analysis. Edited by Wodak, R., and M. Meyer. London, UK: Sage.

Wodak, R. (2002). 'Critical Discourse analysis,' In Handbook in Discourse analysis. Edited by Schiffrin, D. Oxford, UK:Blackwells.

\section{EtelaatNewpaper}

Da'vatemoftizadehbarayeKonfranseSanandaj ]Moftizadeh's invitation regarding Sanandaj conference]. (29 March 1979). Etelaat Newspaper, p.3.

Dar Kordestanniruyetajzyetalabvojudnadarad:mosahebebaAbdol-rahmanGhasemlou [there is no separatist group in Kurdistan: interview with Abdul-rahmanGhasemlou]', (29 March 1979). Etelaat Newspaper, p.8.

Dar mahabad 14 nafarkoshteshodand [14 persons were killed in Mahabad]. (13 February 1979). Etelaat Newspaper, p.2.

KongreyebozorgeKordhadarMahabad [The massive assembly of Kurds in Mahabad]. (3 March 1979). Etelaat Newspaper, p.7.

Kordhashureshratakzibkardand [Kurds denied the riots]. (28 February 1979). Etelaat Newspaper, p. 2.

Marge 3 nafarSanandajraazadarkard [Three death bereaved Sanandaj]. (29 March 1980). Etelaat Newspaper, p.3.

Moftizadeh: man kandideraysatjomhurinistam [Moftizadeh: I am not a candidate for being president of the country]. ( 29 March 1979). Etelaat Newspaper, p.3.

PasokheAlameMoftizadehbe Ayatollah Rohani [Moftizadeh's response to Ayatollah Rohani]. (29 March 1979). Etelaat Newspaper, p.3.

Pavehazzedeenghelabpak shod [Anti-revolutionists were eradicated from Paveh]. (3 March 1980). Etelaat Newspaper, p.4.

Refrandumdarmahabadbargozarnashod [the referendum did not happened in Mahabad]. (29 March 1979). Etelaat Newspaper, p.5.

TarhekhodmokhtaryeKordha [Kurds' autonomy plan]. (3 March 1979). Etelaat Newspaper, p. 7. 


\section{Keyhan Newspaper}

15 nafareeraqidarjangbakordhakoshteshodand [15 Iraqi army’s officers were Killed in Kurdistan's]. (10 March 1980). Keyhan Newspaper, p.15.

Emperialism be masaleyeKordestandamanmizanad [Imperialism agitates Kurdistan's issue]. (26 March 1979). Keyhan Newspaper, p.3.

Kordestanmasaleyehaademamlekatasat[ Kurdistan's issue is the critical issue of the country]. (27 March 1979). Keyhan Newspaper, p.8.

Kordhanabayaddar hade yekaghalyatemazhabibemanadn:mosahebeba Ahmad Moftizadeh [ Kurds should not remained only as a religious minority: an interview with Ahmad Moftizadeh]. (27 March 1979). Keyhan Newspaper, p.8

Shora-ye MaKtabe-Quran-e Kurdistan [Kurdistan's Council of MQ]:

Shora-yeMaKtabe-Quran-e Kurdistan [Kurdistan's Council of MQ] (2000). The $1^{\text {ST }}$ Manifesto.

Shora-yeMaKtabe-Quran-e Kurdistan [Kurdistan's Council of MQ] (2000).Jozwe-ye Didga[Perspectiv Booklet].

Shora-ye Modiriate-e Makab-e Quran [The MQ's Council of management] (2000).The $1^{\text {st }}$ Manifesto, 8 April 2000.

Shora-ye Modiriate-e Makab-e Quran [The MQ's Council of management] (2002).The $2^{\text {nd }}$ Manifesto, 2 December 2002.

Shora-ye Modiriate-e Makab-e Quran [The MQ's Council of management] (2006).CDye MoghadamtwaOsul" [CD of Introduction and Principles]. 11 September 2006.

Shora-ye Modiriate-e Makab-e Quran(1385) [MQ Management Council]. (2005).Efsha-ye ToteeAleiheMaktab[Disclosure of Conspiracy Against MQ, a pamphlet], 30 June2005. 